Article

\title{
Improvement of Stand-Alone Solar PV Systems in the Maputo Region by Adapting Necessary Parameters
}

\author{
Paxis Marques João Roque ${ }^{1, *(\mathbb{D})}$, Shyama P. D. Chowdhury ${ }^{2} \mathbb{C}$ and Zhongjie Huan ${ }^{1}$ \\ 1 Department of Mechanical and Mechatronics Engineering, Faculty of Engineering and the Built Environment, \\ Tshwane University of Technology, Private Bag X680, Pretoria 0001, South Africa; huanz@tut.ac.za \\ 2 Department of Electrical Engineering, Faculty of Engineering and the Built Environment, Tshwane University \\ of Technology, Private Bag X680, Pretoria 0001, South Africa; ChowdhutySP@tut.ac.za \\ * Correspondence: paxis@uem.mz
}

check for updates

Citation: Roque, P.M.J.; Chowdhury, S.P.D.; Huan, Z. Improvement of Stand-Alone Solar PV Systems in the Maputo Region by Adapting

Necessary Parameters. Energies 2021, 14, 4357. https://doi.org/10.3390/ en14144357

Academic Editors: Ana

Cabrera Tobar, Alessandro

Massi Pavan and Silvano Vergura

Received: 30 May 2021

Accepted: 29 June 2021

Published: 19 July 2021

Publisher's Note: MDPI stays neutral with regard to jurisdictional claims in published maps and institutional affiliations.

Copyright: (c) 2021 by the authors. Licensee MDPI, Basel, Switzerland. This article is an open access article distributed under the terms and conditions of the Creative Commons Attribution (CC BY) license (https:/ / creativecommons.org/licenses/by/ $4.0 /)$.
Abstract: With the energy crisis and the constant blackout in the Mozambique Power Company grid, the option of applying solar photovoltaic (PV) systems has been one of the most used alternatives in the neighborhoods of the Maputo region. However, inefficient power delivery caused by unproper sizing and installation of stand-alone solar PV systems has been contributing to the low utilization of solar energy potential in the Maputo region. The optimal sizing and installation of the solar PV system is addressed to evaluate the influence of installation and operation parameters on the power output of PV modules. In this topic, PV modules parameters such as cell temperature, the module's slope and azimuth angles, the losses caused by excessive heating of the module cells, shadows and dust on the PV module and the cooling process at the back of the module are assessed in order to find out the consequence of inadequate installation and operation parameters of solar PV systems in the Maputo region. The proper sizing and installation of the stand-alone solar PV system is fundamental to guarantee the continuous and efficient supply of power and, thus, different tools and techniques have been applied. This study will deal with the hybrid optimization of multiple energy resources (HOMER) and system advisor model (SAM), to size and improve power generation of solar PV systems. This study concluded that for the Maputo region, the optimal tilt angle is $23 \pm 2^{\circ}$ and the azimuth angle is $11 \pm 2^{\circ}$. In addition, for optimization of the tilt and azimuth angles, it also examined the effect of module backside ventilation and proved that the system's power generation increases with the rise of spacing between the module and the wall, since the strategy prevents the decline of the module cells efficiency. However, the maximum recommended spacing between the PV module and the mounting wall is about $0.4 \mathrm{~m}$, since an effort to increase the spacing up to this level results in an insignificant growth of power output.

Keywords: PV installation; PV operation; PV power generation; PV efficiency

\section{Introduction}

Awareness about the use of renewable energies has been increasing in Mozambique and, therefore, solar energy has found great application as an alternative energy source in the Maputo region. However, the impact of solar PV systems in solving the energy crisis in Mozambique has been insignificant due to the lack of knowledge regarding the installation and proper operation of PV systems. Furthermore, social and economic factors have created barriers in the application of solar systems in the Maputo region. The performance of the PV module depends on distinct factors: solar radiation, ambient temperature, wind speed and direction, panel material composition, and mounting procedure [1-6]. Therefore, in most commercial PV modules, the portion of solar radiation converted into electricity ranges from $13 \%$ to $20 \%[7,8]$. In that context, the integration of that range of parameters into an optimization analysis for energy loss reduction and performance improvement is a task that has only been partially addressed by a few studies [9]. The goal of implementing more effective PV systems installation and operation solutions leads towards the innovations 
throughout the solar PV value chain [10]. In the last decades, performance improvements of PV systems have come under intense discussions [11]. One of the key weaknesses of solar PV modules is the sensitivity of the module cell's efficiency to high temperatures, especially in regions with long hot seasons such as Maputo, which validates the relevance of this study to investigate the thermal losses of the solar systems.

\section{Analysis of Installation and Operating Parameters of Solar PV Systems}

Normally, the efficiency of photovoltaic systems is low compared with that of traditional thermal or hydroelectric plants $[10,11]$. In order to overcome this disadvantage, low available solar input could be maximized by orienting the photovoltaic cells in the direction of the sun to capture the maximum energy possible with high efficiency [12-15]. The analysis of solar radiation capture conditions on an arbitrarily oriented surfaces is quite complex and consider the Sun-Earth geometric relationship. Therefore, the amount of radiation differs throughout the year because of the variation of the distance between the Sun and the Earth [15]. Considering that the Earth rotates tilted around its axis, leading to an ecliptic orbital plane around the Sun, this slope causes cyclic variation of solar radiation available in the distinct location of the Earth [16]. According to [16-18], the solar declination angle can be estimated as:

$$
\delta_{\text {solar }}=23.45^{\circ} \cdot \sin \left(360 \frac{284+n}{365}\right)\left[^{\circ}\right]
$$

where: $n$ is the day number of the year.

Considering that solar radiation is focusing on a PV panel, Figure 1 helps to examine the slope and orientation angles of the PV module and the parameters indicated in Figure 1 can be correlated by the expression:

$$
\cos i_{a}=\cos \alpha \cdot \cos \left(a_{s}-a_{w}\right) \sin \beta+\sin \alpha \cdot \cos \beta
$$

where $\alpha$ is the solar altitude angle $\left({ }^{\circ}\right), a_{S}$ is the solar Azimuth angle $\left(^{\circ}\right), \beta$ is the PV module slope angle $\left({ }^{\circ}\right), a_{w}$ is the PV module Azimuth angle $\left({ }^{\circ}\right)$, and $i_{a}$ is the incident angle $\left(^{\circ}\right)$.

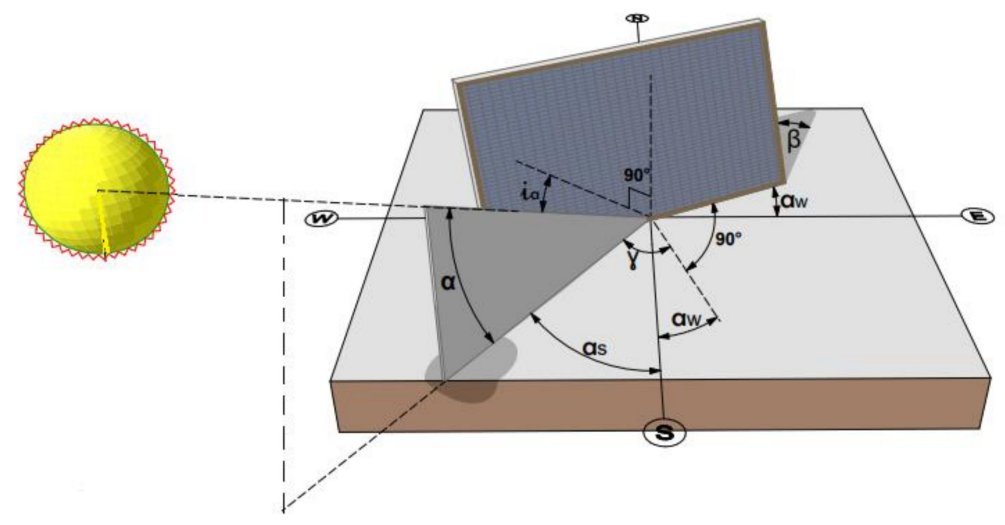

Figure 1. Definitions of solar angles for a tilted PV module.

The solar altitude angle can be correlated to the solar declination by the expression:

$$
\sin \alpha=\sin L \cdot \sin \delta_{\text {solar }}+\cos L \cdot \sin \delta_{\text {solar }} \cdot \cos H_{S}
$$

where $L$ is the latitude angle $\left(^{\circ}\right), \delta_{\text {solar }}$ is the solar declination angle $\left(^{\circ}\right)$, and $H_{S}$ is the solar hour angle based on the nominal time of $24 \mathrm{~h}$ required for the sun to move $360^{\circ}$ around the Earth $\left(^{\circ}\right)$; 
The solar Azimuth angle can be computed as:

$$
\sin a_{s}=\cos \delta_{\text {solar }} \cdot \frac{\sin H_{s}}{\cos \alpha}
$$

Considering the parameters indicated in Figure 1, solar radiation on an arbitrary sloped PV module is estimated as:

$$
\bar{G}_{s}=\bar{G}_{b}+\bar{G}_{d}+\bar{G}_{r}\left[\mathrm{~kW} / \mathrm{m}^{2}\right]
$$

where $\bar{G}_{b}$ is the bean diffuse solar radiation $\left(\mathrm{kW} / \mathrm{m}^{2}\right), \bar{G}_{d}$ is the sky diffuse solar radiation $\left(\mathrm{kW} / \mathrm{m}^{2}\right)$, and $\bar{G}_{r}$ is the ground reflected solar diffuse radiation $\left(\mathrm{kW} / \mathrm{m}^{2}\right)$.

The diffuse radiation on the surface can be computed as:

$$
\bar{G}_{d s}=\bar{G}_{d s(h)} \cdot \cos ^{2}(\beta / 2)\left[\mathrm{kWh} / \mathrm{m}^{2}\right]
$$

where $\bar{G}_{d s(h)}$ is the diffuse radiation on horizontal surface $\left(\mathrm{kWh} / \mathrm{m}^{2}\right)$ and $\beta$ is the PV module slope angle $\left(^{\circ}\right)$.

The ground reflected solar diffuse radiation intercepted by the sloped surface can be calculated by:

$$
\bar{G}_{r}=\psi\left(\bar{G}_{b, N} \cdot \sin \alpha+\bar{G}_{d s(h)} \cdot \sin (\beta / 2)\left[\mathrm{kWh} / \mathrm{m}^{2}\right]\right.
$$

where $\bar{G}_{d s(h)}$ is the diffuse radiation on horizontal surface $\left(\mathrm{kWh} / \mathrm{m}^{2}\right), \beta$ is the PV module slope angle $\left(^{\circ}\right), \psi$ is the ground reflectance, and $\bar{G}_{b, N}$ is the direct solar radiation $\left(\mathrm{kWh} / \mathrm{m}^{2}\right)$.

In energy conversion, socioeconomic constraints and environmental concerns became a persuasive factor that contributed to the improvement of power systems [19-25]. In that context, sustainable energy has two key components: renewable energy and energy efficiency [26,27]. The operating temperature of photovoltaic modules represents a key parameter affecting their conversion efficiency. High operating temperatures of solar PV systems leads to a decline of maximum power output in the similar conditions of solar radiation [28].

Due to the unpredictability of the sunlight, storage systems or backup generators are often required, greatly increasing investment costs. Many correlations have been developed for the cell temperature $T_{c}$ as a function of climatic parameters (solar radiation, ambient air temperature, wind speed, etc.). According to Dubey et al. [29], in most practical applications the following linear relation for the cell efficiency can be used with significant accuracy:

$$
\eta_{c}=\eta_{r e f}\left(1-\frac{T_{c}-T_{r e f}}{T_{o}-T_{r e f}}\right)[\%]
$$

where $\eta_{\text {ref }}$ is the efficiency of the photovoltaic cell at temperature $T_{r e f}(\%), T_{r e f}$ is the reference temperature, usually $25^{\circ} \mathrm{C}$, and $T_{o}$ is the maximum temperature at which the efficiency of the photovoltaic cell decreases to zero $\left({ }^{\circ} \mathrm{C}\right)$.

The maximum cell temperature is a key operating parameter to decide the quality and performance of a solar PV. According to Chander et al. [8], a typical nominal operative cell temperature, ranges between 43 and $47^{\circ} \mathrm{C}$, which is also dependent on the manufacturer's specifications.

Similar to other power conversion technologies, there are some technical aspects and operating factors that can significantly influence production rates of solar PV modules, contributing to the increase in losses $[4,7,30,31]$. In order to improve solar PV modules performance, optical, electrical, and thermal losses need to be minimized. According to Armstrong et al. [7], the variability of wind speed and directions influences solar PV module losses and, thus, thermal losses can be estimated as:

$$
Q_{T f_{-} \text {loss }}=C_{f_{\_} \text {loss }}+W_{f_{-} \text {loss }} \cdot u_{\text {wind }}\left[\mathrm{W} / \mathrm{m}^{2} \mathrm{~K}\right]
$$


where $Q_{T f_{-} \text {loss }}$ is the thermal loss rate $\left(\mathrm{W} / \mathrm{m}^{2} \mathrm{~K}\right), C_{f_{-} \text {loss }}$ is the constant loss factor, $W_{f_{-} \text {loss }}$ is the wind loss factor, and $u_{\text {wind }}$ is the wind speed $(\mathrm{m} / \mathrm{s})$.

The thermal performance of the PV is evaluated by the energy balance between ambient temperature and the cell heating process due to incident irradiance and, thus, the PV module maximum power point (MPP) will be influenced by the thermal effect since the cell temperature changes according to the equation:

$$
T_{\text {cell }}=T_{a m b}+\frac{\psi \bar{G}_{s\left(\beta, \alpha_{w}\right)}\left(1-\eta_{P V}\right)}{Q_{T f_{-} \text {loss }}}\left[{ }^{\circ} \mathrm{C}\right]
$$

where $T_{\text {cell }}$ is the cell temperature $\left({ }^{\circ} \mathrm{C}\right), Q_{T f_{-} \text {loss }}$ is the thermal loss rate $\left(\mathrm{W} / \mathrm{m}^{2} \mathrm{~K}\right), T_{\text {amb }}$ is the ambient temperature $\left({ }^{\circ} \mathrm{C}\right), \psi$ is the absorption, $\bar{G}_{s\left(\beta, \alpha_{W}\right)}$ is the solar radiation on the PV module considering the optimal tilt angle $\left(^{\circ}\right)$ and azimuth angle $\left(^{\circ}\right)$ in $\left(\mathrm{kWh} / \mathrm{m}^{2}\right)$, and $\eta_{P V}$ is the cell efficiency.

In that context, during the operation of the solar PV module, excessive heat can result in energy losses [4,7,31]. According to Armstrong et al. [7], the thermal capacitance of the PV module material associated with the absorption of heat is expressed as:

$$
q_{T H_{-} p v}=\rho c A_{s p v} t\left[\mathrm{~J} /{ }^{\circ} \mathrm{C}\right]
$$

where $\rho$ is the density of the PV module material $\left(\mathrm{kg} / \mathrm{m}^{3}\right), c$ is the specific heat capacity $\left(\mathrm{J} / \mathrm{kg}{ }^{\circ} \mathrm{C}\right), A_{s}$ is the PV module surface $\left(\mathrm{m}^{2}\right)$, and $t$ is the thickness of the PV module material (m).

Considering that the interaction between the air flow and the PV panel causes the heat transfer phenomena by the external convection mechanism, this interaction will affect the PV module performance. According to Hammami et al. [30], the convection coefficient due to the wind flow over the PV surface can be estimated from the equation:

$$
h_{\text {conv }}=\frac{N u \cdot k_{T H}}{L_{p}}\left[\mathrm{~W} / \mathrm{m}^{2 \circ} \mathrm{C}\right]
$$

where: $h_{\text {conv }}$ is the natural convection coefficient $\left(\mathrm{W} / \mathrm{m}^{2}{ }^{\circ} \mathrm{C}\right), N u$ is the Nusselt number, $k_{T H}$ is the thermal conductivity $\left(\mathrm{W} / \mathrm{m}{ }^{\circ} \mathrm{C}\right)$, and $L_{p}$ is the length of the panel crossed by the air flow (m).

For natural convection, the Nusselt number can be estimated from the empirical Churchill and Chu equation considering a range of Reynolds and Prandtl numbers and therefore [30]:

$$
N u_{\text {nat }}=\left(0.825+\frac{0.387 R_{a}^{\frac{1}{6}}}{\left[1+\left(\frac{0.492}{P_{r}}\right)^{\frac{9}{16}}\right]^{\frac{8}{27}}}\right)^{2}
$$

where: $R_{a}$ is the Rayleigh number and $P_{r}$ is the Prandtl number and can be found in tables of air proprieties.

The Rayleigh number $(R a)$ describes the relationship between momentum diffusivity and thermal diffusivity and is computed as:

$$
R_{a}=G_{r} \cdot P_{r}=\frac{g \phi\left(T_{p v p}-T_{a i r}\right) L_{p}^{3}}{v^{2}} P_{r}
$$

where $G_{r}$ is the Grashof number, $g$ is the gravity acceleration $\left(\mathrm{m} / \mathrm{s}^{2}\right), \phi$ is the volumetric expansion coefficient for ideal gases $\left(\mathrm{K}^{-1}\right), T_{p}$ is the panel temperature $\left({ }^{\circ} \mathrm{C}\right), T_{a i r}$ is the air temperature $\left({ }^{\circ} \mathrm{C}\right), v$ is the kinematic viscosity $\left(\mathrm{m}^{2} / \mathrm{s}\right)$, and $L_{p}$ is the length of the flat surface crossed by the air flow $(\mathrm{m})$. 
Regarding forced convection, depending on the nature of the flow, the average Nusselt number over a flat surface can be empirically estimated by Equation (15), for laminar flow, and by the Equation (16), for turbulent flow. For flow over a flat plate, the transition from laminar to turbulent flow usually occurs at the critical Reynolds number of $5 \times 10^{5}$ [32].

$$
\begin{gathered}
N_{u}=0.664 \operatorname{Re}_{L}^{0.5} \cdot P_{r}^{\frac{1}{3}} \operatorname{Re}<5 \cdot 10^{5} \\
N_{u}=0.037 \operatorname{Re}_{L}^{0.8} \cdot P_{r}^{\frac{1}{3}} 5 \cdot 10^{5} \leq \operatorname{Re} \leq 10^{7}
\end{gathered}
$$

where $R e$ is the Reynolds number.

In the analysis of internal and external flow over pipes and surfaces, Reynolds number represents an important parameter in the characterization of the flow. Reynolds number describes the relationship between inertia and viscous force and is expressed as:

$$
\operatorname{Re}=\frac{u \cdot L_{p}}{v}
$$

where $u$ is the air flow speed $(\mathrm{m} / \mathrm{s}), v$ is the kinematic viscosity $\left(\mathrm{m}^{2} / \mathrm{s}\right)$, and $L_{p}$ is the length of the flat surface crossed by the air flow (m).

\section{Solar PV Power Output}

While operating PV solar systems it is important to ensure some measures in order to avoid the decrease of the PV cell efficiency [33]. According to [34], one of the main problems affecting the performance of solar PV technology is the dust that accumulates on the surface of the modules through the year and, thus, PV modules surfaces must be kept free of dust. The design of experiments that allow one to compare the efficiency of a PV solar module with dust and a similar one without dust have been showing the impact of dust on PV solar modules [2,34].

In solar PV systems, photovoltaic cells convert solar radiation into electricity and, therefore, a critical parameter for installing fixed-tilt panels is the slope angle $[15,20]$. In a proper installation and operation condition, the electrical output, measured at the collector array terminals of a PV system, is expressed as:

$$
P_{\text {array }}=P_{\text {mod }} \cdot \bar{G}_{s\left(\beta, \alpha_{w w}\right)} \cdot \varepsilon_{\text {perf }}\left(1-f_{\text {shad }}\right)[\mathrm{kWh} / \mathrm{yr}]
$$

where $P_{\text {mod }}$ is the nominal power of PV module $(\mathrm{kWp}), \bar{G}_{s\left(\beta, \alpha_{W}\right)}$ is the solar radiation on the PV module considering the optimal tilt angle $(\beta)$ and azimuth angle $\left(\alpha_{w}\right)$ in $\left(\mathrm{kWh} / \mathrm{m}^{2}\right)$, $\varepsilon_{\text {perf }}$ is the performance ration, and $f_{\text {shad }}$ is the shading factor.

In the solar PV system, the probable energy losses are difficult to predict a priori accurately and, thus, it is critical to design, install, and operate properly the system considering all the factors that could contribute to energy loss [4,35]. According to [26,36], the electrical power output of a solar PV system can be calculated as:

$$
P_{G_{-} P V}=C_{P V} \cdot f_{P V}\left(\frac{\bar{G}_{i n c i d}}{\bar{G}_{s c}}\right)\left[1+\alpha_{t c}\left(T_{C e l l}-T_{C_{-} s c}\right)\right][\mathrm{kWh}]
$$

where $C_{P V}$ is the rated capacity of the $\mathrm{PV}$ array, meaning its power output under standard test conditions $(\mathrm{kW}), f_{P V}$ is the PV derating factor $(\%), \bar{G}_{\text {incid }}$ is the solar radiation incident on the PV array in the current time step $\left(\mathrm{kW} / \mathrm{m}^{2}\right), \bar{G}_{s c}$ is the incident radiation at standard test conditions $\left(\mathrm{kW} / \mathrm{m}^{2}\right), \alpha_{t c}$ is the temperature coefficient of power $\left(\% /{ }^{\circ} \mathrm{C}\right), T_{\text {Cell }}$ is the $\mathrm{PV}$ cell temperature in the current time step $(\%)$, and $T_{\mathrm{C}_{-} s c}$ is the PV cell temperature under standard test conditions. Normally it is between 20 and $25^{\circ} \mathrm{C}$.

When applying SAM, since temperature at the back of the PV module affects the module's performance, SAM estimates the module's back temperature based on the inci- 
dent solar radiation, $a$ and $b$ coefficients, and the ambient temperature and wind speed by the equation:

$$
T_{\text {back }}=\bar{G}_{\text {incid }} \cdot e^{a+b \cdot u_{w}}+T_{a m b}\left[{ }^{\circ} \mathrm{C}\right]
$$

where $\bar{G}_{\text {incid }}$ is the total incident radiation from the weather data processor $\left(\mathrm{W} / \mathrm{m}^{2}, T_{a m b}\right.$ is the ambient temperature $\left({ }^{\circ} \mathrm{C}\right), a, b$ are coefficients empirically determined, accounting for the effect of wind on the module temperature and are presented in Table 1: $a$ defines the module temperature upper limit (at low wind speed and high solar radiation levels) and $b$ defines the rate at which the module temperature decreases as wind speed increases. The values depend on the module's construction, which determines its ability to absorb and shed heat.

Table 1. Values of the coefficients $a, b$, and $d T$. Courtesy of NREL [37].

\begin{tabular}{cccc}
\hline Module Structure and Mounting & $(\boldsymbol{a})$ & $(\boldsymbol{b})$ & $d T\left({ }^{\circ} \mathbf{C}\right)$ \\
\hline Glass/Cell/Polymer Sheet (open rack) & -3.56 & -0.075 & 3 \\
Glass/Cell/Glass (open rack) & -3.47 & -0.059 & 3 \\
Polymer/Thin Film/Steel (open rack) & -3.58 & -0.113 & 3 \\
Glass /Cell/Polymer Sheet (insulated back) & -2.81 & -0.045 & 0 \\
Glass/Cell/Glass (close roof mount) & -2.98 & -0.047 & 1 \\
Concentrating PV Module & -3.2 & -0.09 & 17 \\
\hline
\end{tabular}

Next, the cell temperature is calculated based on the module back temperature, incident radiation, and $\mathrm{dT}$ :

$$
T_{\text {Cell }}=T_{\text {back }}+\left(\frac{\bar{G}_{\text {incid }}}{\bar{G}_{s c}}\right) \cdot d T\left[{ }^{\circ} \mathrm{C}\right]
$$

After calculating the $T_{\text {Cell }}$ by Equation (21) (considering the temperature at the back of the module), the electrical power output of a solar PV system can again be calculated and the results before correction and after correction compared.

\section{Case Study of Solar PV Systems in the Maputo Region}

Energy access has increased significantly in Maputo in recent decades as a result of the government's effort to provide energy to all citizens through implementation of energy policies, an expansion of the electricity grid, and an increase of generation capacity. The trade of power generation technologies has found a good market in Maputo and, thus, solar PV system components are of easy access. However, even with this market opening, there is still a lack of knowledge regarding the potential of solar systems and its installation and operation procedure that could spread the application of solar technology. The Maputo province in Mozambique has high global irradiation when compared with other good locations in Europe and Asia. Maputo's global horizontal irradiation is about $1785 \mathrm{kWh} / \mathrm{m}^{2} /$ year and its solar power potential is estimated to be $400 \mathrm{MW}$ [38].

Figures 2 and 3 illustrate the monthly distribution of solar global horizontal irradiance and average ambient temperature in the Maputo province areas. As it is observed, the province has an average clearness rate of about $60 \%$, radiation of $5.6 \mathrm{kWh} / \mathrm{m}^{2} /$ day, and average monthly ambient temperature of about $30{ }^{\circ} \mathrm{C}$ in summer and $25^{\circ} \mathrm{C}$ in winter. It should be noted that, in recent years, the average monthly temperature has been rising significantly due to climate changes and global warming. 


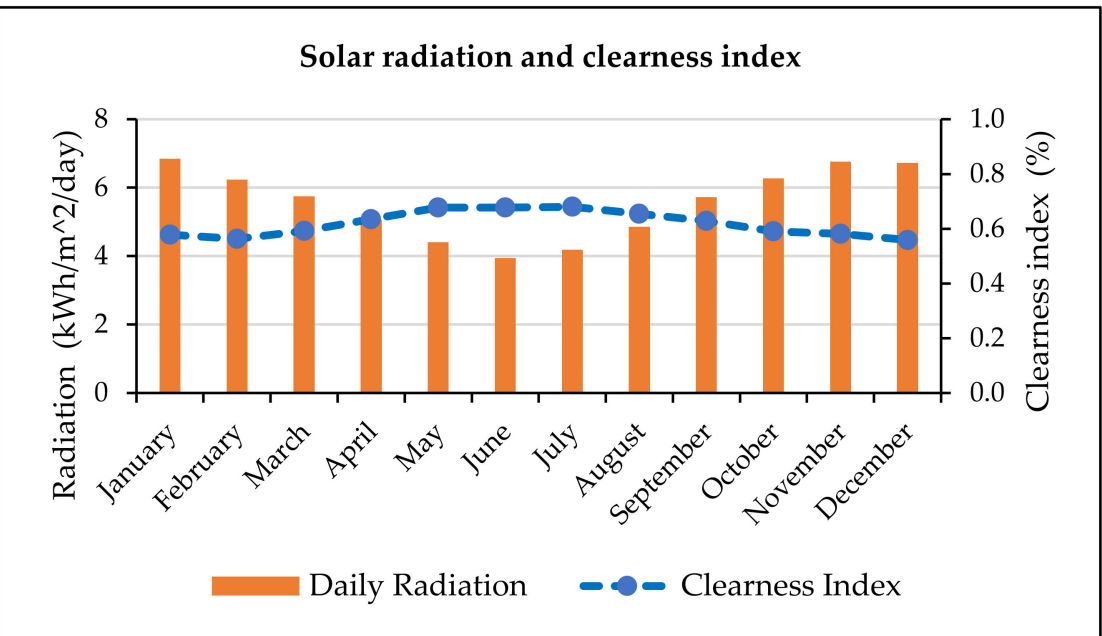

Figure 2. Solar radiation and clearness index. Courtesy of HOMER [39].

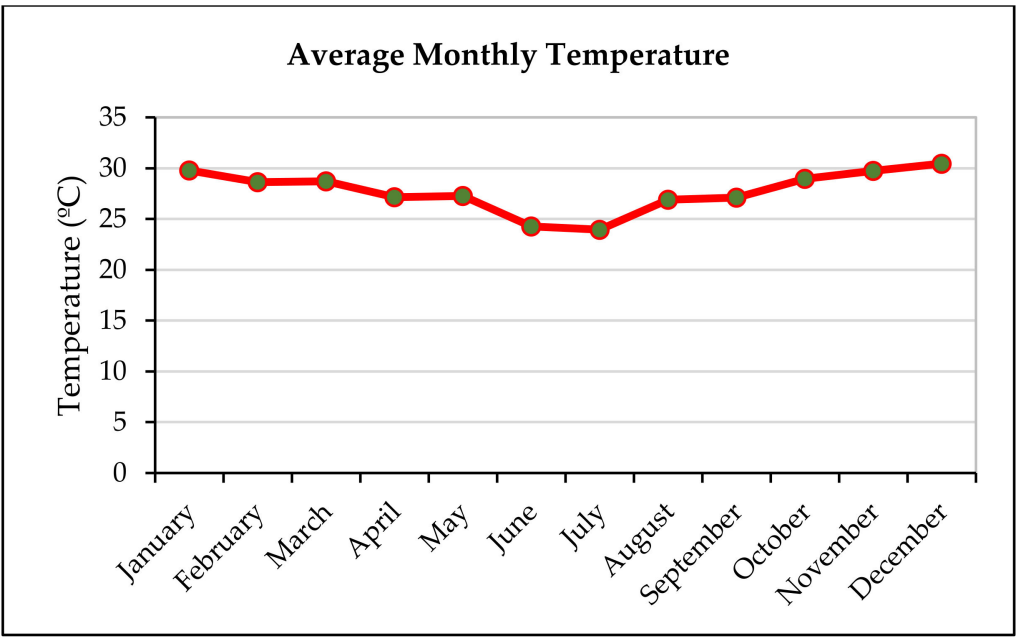

Figure 3. Average monthly ambient temperature between 1997 and 2010. Courtesy of HOMER [39].

Figures 4 and 5 illustrate solar PV systems in operation in the Matola district and by comparing the mode of installation a significant difference of the module tilt angle between the systems is noted.

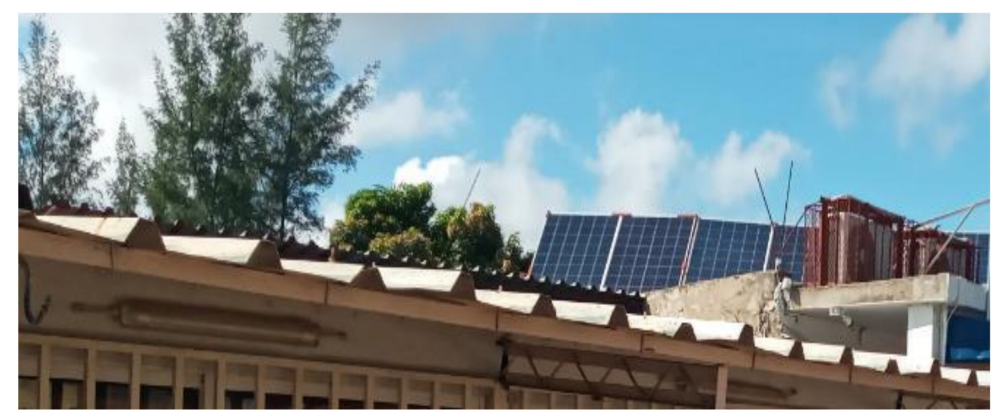

Figure 4. Solar PV system in Matola N2 (A). 


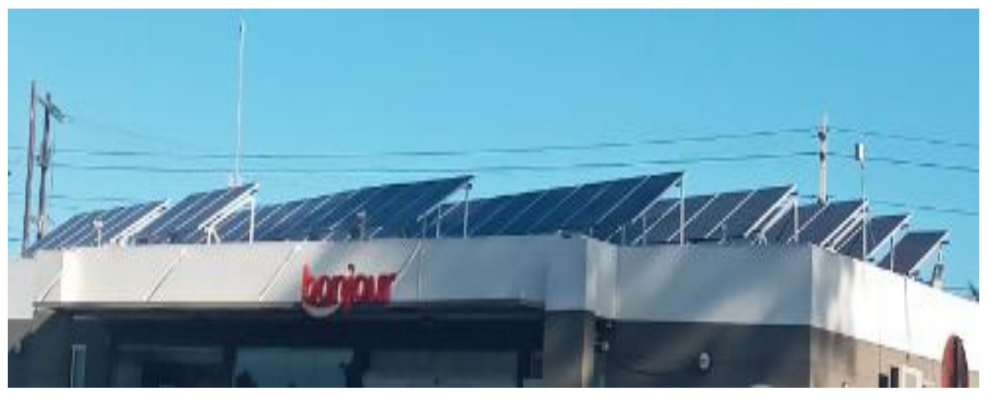

Figure 5. Solar PV system in Matola N4 (B).

In Figure 6, it is observed that both solar systems are facing the north, but the azimuth angle is slightly different. Note that the distance between point A and B is about $12 \mathrm{~km}$.

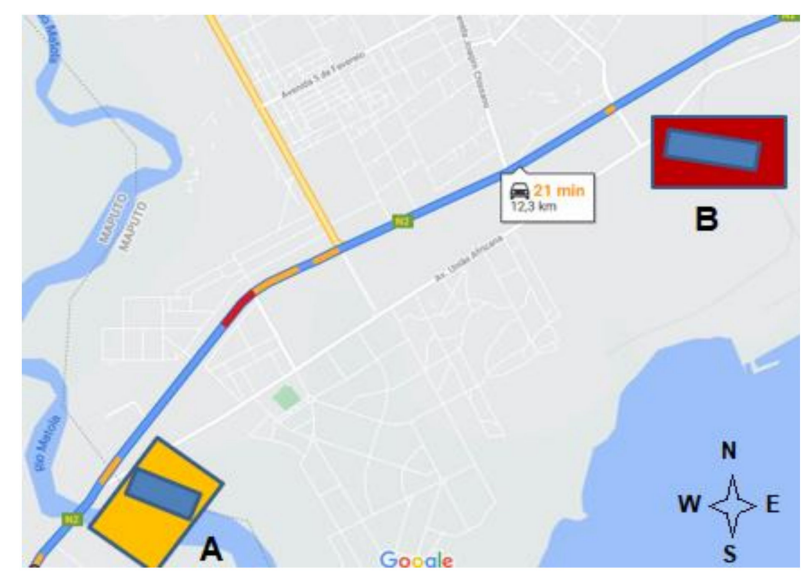

Figure 6. Definitions of solar angles for a tilted surface.

In this study, HOMER and SAM optimization tools for electric renewable systems were used to size a hybrid solar PV system for a building with an estimated peak of power consumption of about $5.0 \mathrm{~kW}$. The building's daily load profile is presented in Figure 7.

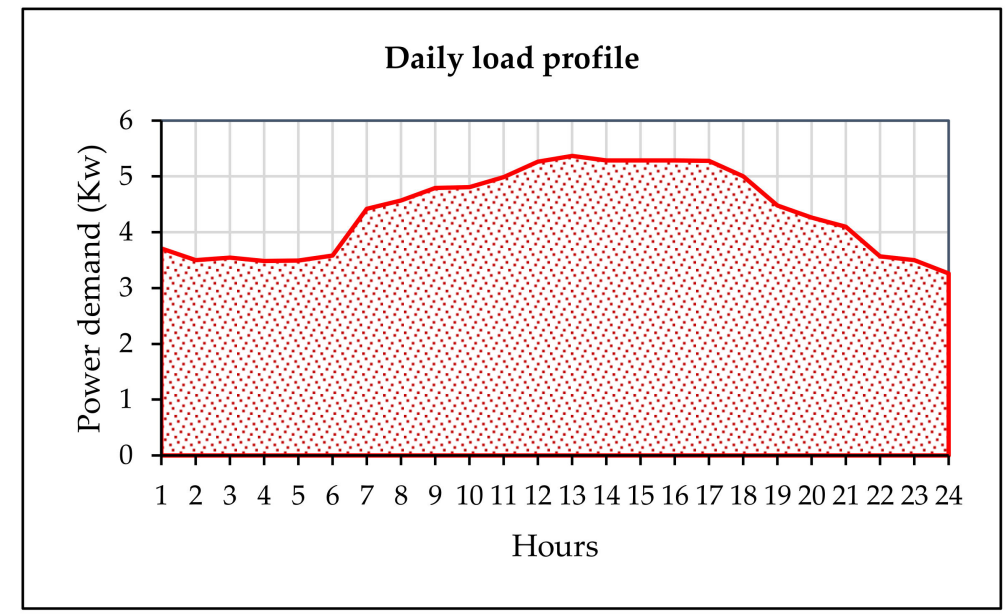

Figure 7. The building's daily average load profile in January 2016. Courtesy of EDM [40].

Considering the daily load profile, the availability of energy resources and investment costs, HOMER sized the capacity of the hybrid system composed by a $12.6 \mathrm{~kW}$ solar PV system, a $6.0 \mathrm{~kW}$ power storage bank, and a $6.0 \mathrm{~kW} \mathrm{DC/AC} \mathrm{inverter.}$

Although in many sizing and placement studies of hybrid solar PV systems the economic aspects are considered important, this project is basically concerned with the sizing 
and evaluation of the power output through the analysis of installation and operation parameters. Since HOMER optimized the system's capacity, SAM examined the system's performance. Therefore, the module's tilt and azimuth angle, the module's electric configuration design, and the losses parameters (module's shading and the heating and ventilation effect) were the assessed variables in the performance analysis of the system.

Figure 8 and Table 2 present the monocrystalline module characteristics, while Figure 9 and Table 3 present the inverter characteristics.

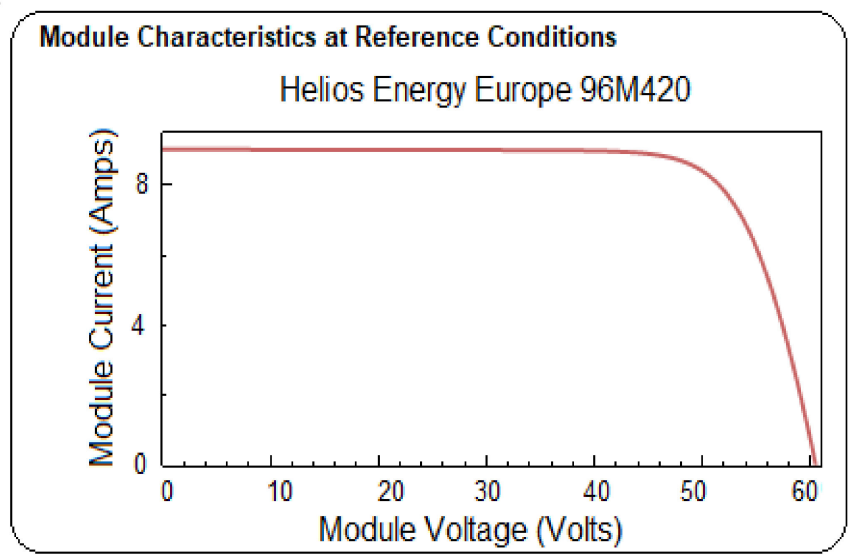

Figure 8. Module's I-V curve. Courtesy of NREL [37].

Table 2. Module characteristics at reference conditions. Courtesy of NREL [37].

\begin{tabular}{ccc}
\hline Parameter & Value & \\
\hline Nominal efficiency & 16.32 & $\%$ \\
Maximum power (pmp) & 420.01 & Wdc \\
Maximum power voltage (Vmp) & 49.50 & Vdc \\
Maximum power current (Imp) & 8.50 & Adc \\
Open circuit voltage (Voc) & 60.50 & Vdc \\
Short circuit current (Isc) & 9.00 & Adc \\
\hline
\end{tabular}

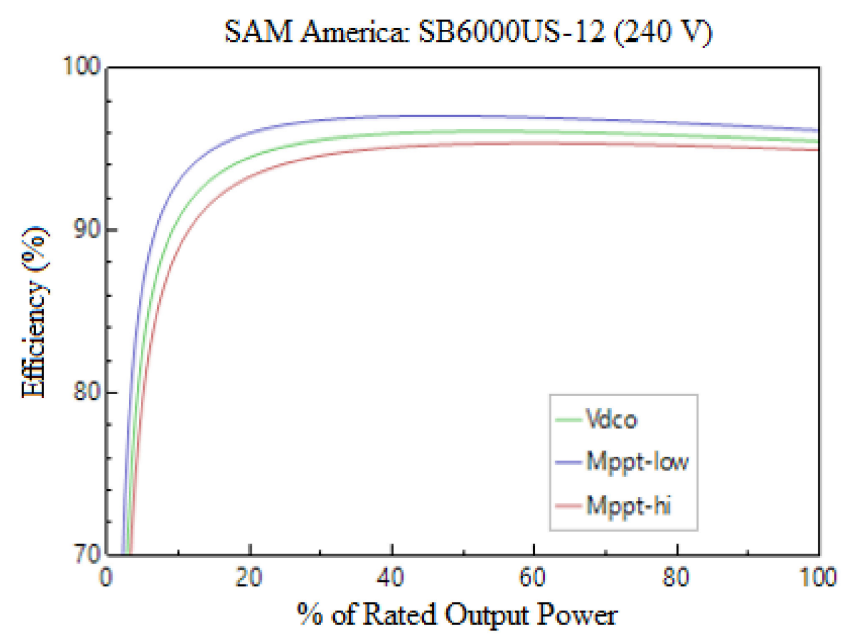

Figure 9. Inverter efficiency curve. Courtesy of NREL [37]. 
Table 3. Inverter characteristics. Courtesy of NREL [37].

\begin{tabular}{ccl}
\hline Parameter & Value & \\
\hline Maximum AC power & 6000.00 & Wdc \\
Maximum DC power & 6282.08 & Wdc \\
Power use during operation & 51.58 & Wdc \\
Power use at night & 1.80 & Wdc \\
Nominal AC voltage & 240.00 & Vdc \\
Maximum DC voltage & 480.00 & Vdc \\
Maximum DC current & 20.25 & Adc \\
Minimum MPPT DC voltage & 100.00 & Vdc \\
Nominal DC voltage & 310.00 & Vdc \\
Maximum MPPT DC voltage & 480.00 & Vdc \\
\hline
\end{tabular}

Regarding the storage system, a lithium-ion battery bank was selected (see Table 4) and then the model moved to the system design.

Table 4. Lithium-ion battery bank characteristics. Courtesy of HOMER [39].

\begin{tabular}{ccc}
\hline Parameter & Value & \\
\hline Nominal voltage & 39.60 & $\mathrm{~V}$ \\
Nominal capacity & 53.00 & $\mathrm{kWh}$ \\
Nominal capacity & 256.00 & $\mathrm{Ah}$ \\
Roundtrip efficiency & 86.00 & $\%$ \\
Maximum charge current & 151.50 & $\mathrm{~A}$ \\
Maximum discharge current & 151.50 & $\mathrm{~A}$ \\
\hline
\end{tabular}

In SAM, the power output of the system was evaluated considering the following methods:

- The tilt and azimuth angle tracking method—evaluating the system's power output for different tilt and azimuth angles, SAM provides four possibilities: fixed tilt and azimuth angles, rotation of the module on one of its axes, rotation of the module on one of its axes and its support, and finally the azimuth angle tracking option. In this study, the first option (fixed tilt and azimuth angles) was used as a basic case. As the methodology to track the optimal tilt angle, the azimuth angle was fixed equal to $0^{\circ}$ and the tilt angle varied from 5 to $35^{\circ}$ (Case-1). After optimizing the tilt angle, the azimuth varied from 0 to $30^{\circ}$ to track the best angle (Case-1A).

- Heat transfer method-examining the effect of ventilation at the back side of the module, in order to perform this analysis, SAM uses four mounting configuration options (rack, flush, integrated, and gap). In the rack configuration, the environment air flows freely over the front and back of the modules. In the flush configuration, the modules are in direct contact with the roof or wall and the environment air cannot flow over the back of the module. In the integrated mounting mode, the modules are part of the roof or wall and in the gap mounting mode, the modules are mounted to ensure a limited air flow over the backside of each module. In this study, the gap mounting mode (Case-2) and the integrated mounting mode (Case-3) were applied to assess thermal losses and module cell temperature. In Case-2 (the gap mounting mode), the space between the module's back and the roof surface varied from 0 to $1.8 \mathrm{~m}$ in order to examine the effect of the natural flux of the air at the backside of the PV solar module. In Case-3, the integrated mounting mode was used to evaluate the effect of the module's backside temperature.

\section{Results and Discussion}

The improvement of the system's performance followed two principles applied by SAM to design the solar PV system, the slope and azimuth angle tracking method, and the heat transfer method. The first principle was considered for Case- 1 and the second 
principle for Cases-2 and -3. Since Maputo is located in the Southern Hemisphere, the PV module faces the north and the tilt and azimuth angle can be presented as in Figure 10.

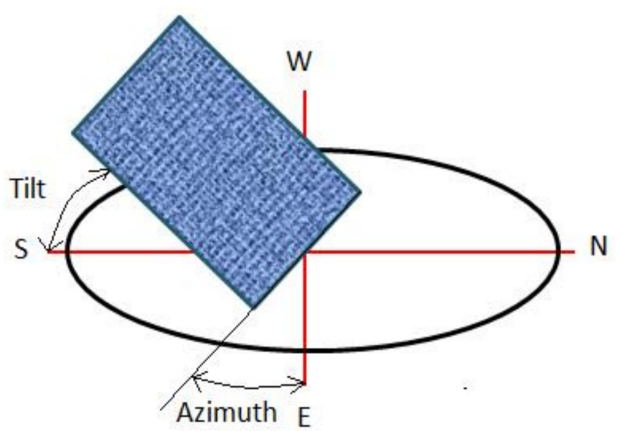

Figure 10. System's tilt and azimuth angles representation.

The results of the Case-1 presented in Figure 11 prove that the performance of the solar PV systems is correlated to the module's slope installation angle. As can be observed, for the analyzed region, the module demands the tilt angle ranges from 20 to $25^{\circ}$.

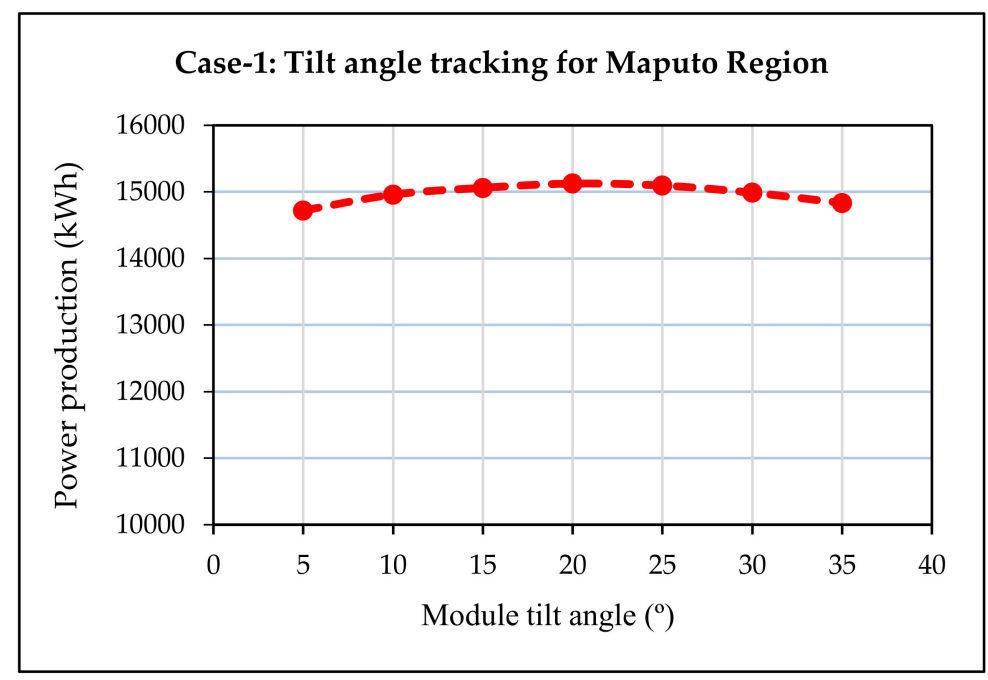

Figure 11. The power output system for distinct tilt angles.

A sensitive analysis on the power output system for this interval of angles demonstrated that for the Maputo region, the best tilt angle was $23 \pm 2^{\circ}$. Concerning the azimuth angle, the results of Case-1A displayed in Figure 12 show that the recommended azimuth angles for the Maputo region can range from 5 to $10^{\circ}$. A sensitive analysis of the electricity generation system for azimuth values close to $10^{\circ}$ showed that the optimal angle was $11 \pm 1^{\circ}$. 


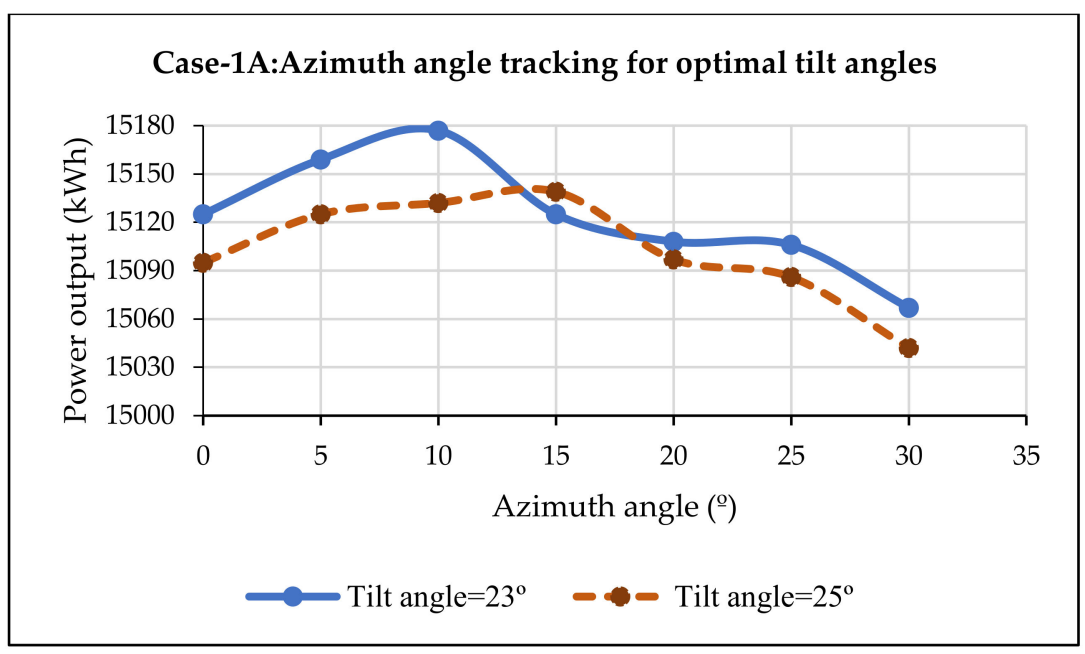

Figure 12. The power output system for distinct azimuth angles.

Regarding the system's operating, the monthly power output is shown in Figure 13 with January accounting for the largest monthly power generation in the first year of operation.

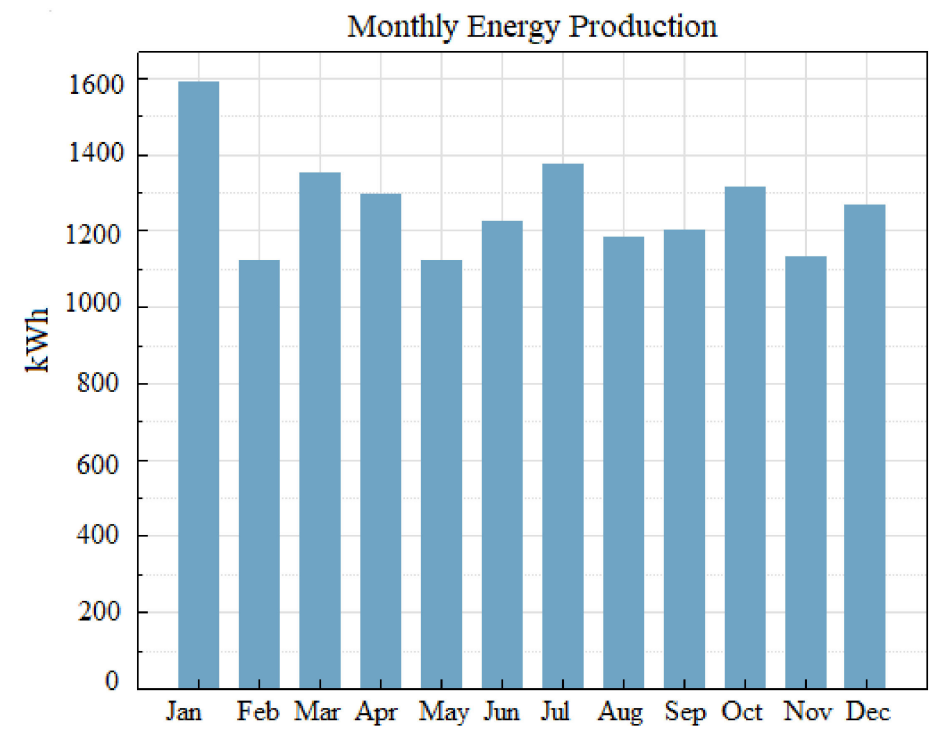

Figure 13. The monthly energy production system of tilt angle $=23^{\circ}$ and azimuth angle $=11^{\circ}$.

In Table 5, other performance information is shown and, thus, the total energy production in year 1 was about $15,180 \mathrm{kWh}$. From the results, special attention was paid to the electricity tariff, computed as $15.40 \propto / \mathrm{kWh}$. Comparing this energy tariff with the commercial tariff charged by Mozambique Power Company, which is about $24.60 \mathrm{k} / \mathrm{kWh}$, there was a saving of 37 percent $(\%)$.

Table 5. Summary results for the operating system at the best tilt and azimuth angles.

\begin{tabular}{ccc}
\hline Metric & Value & \\
\hline Annual energy (year 1) & $15,180.00$ & $\mathrm{kWh}$ \\
Performance ratio (year 1) & 0.60 & $\%$ \\
Battery roundtrip efficiency & 93.31 & $\varnothing / \mathrm{kWh}$ \\
Levelled & 15.40 & (USD) \\
COE & 28,696 & \\
Net Actual cost &
\end{tabular}


Regarding the results of Case-2, it is observed in Figure 14 that by increasing the gap between the module and the roof or the ground, the air flow at the back of the module and the ventilation of the module improves, contributing to the better performance of the PV solar panel. Efficiency of solar PV systems declines with the obstruction of free movement of the air at the backside of the solar panel contributing to the increase of heat losses. In that context, when installing a solar system, besides from using the recommended location of the tilt and azimuth angles, it is suggested to guarantee that the natural convection mechanism removes the heat at the backside of the PV modules.

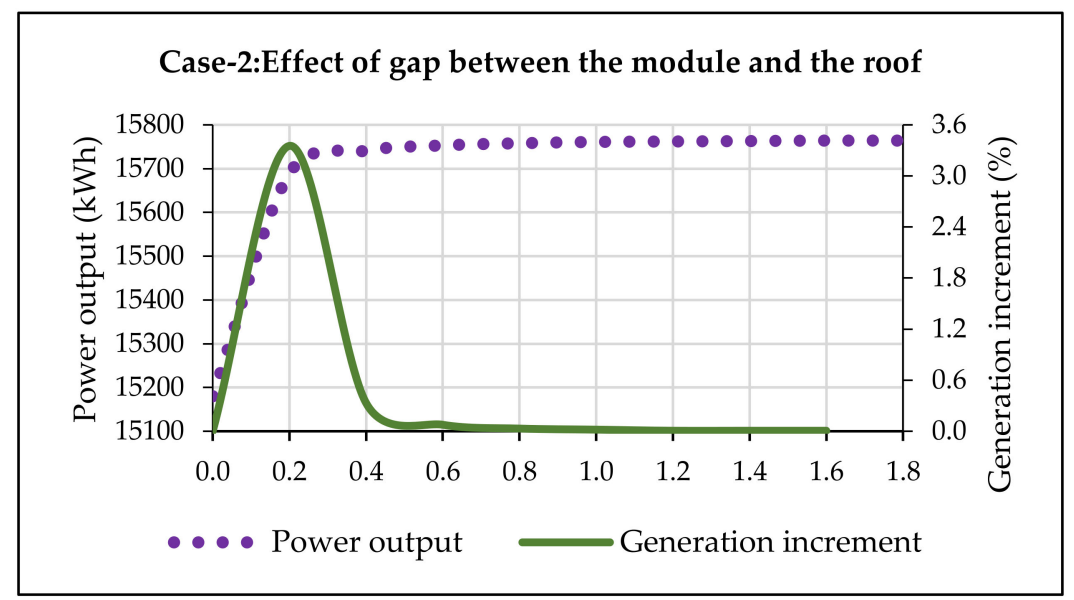

Figure 14. Energy production system for different gaps between the module and roof (tilt angle $=20^{\circ}$ and azimuth angle $=10^{\circ}$ ).

By applying the thermal model into the control of heat losses it is clearly illustrated that the novelty is that the effect of ventilation was significant for spacing between 0.1 and $0.4 \mathrm{~m}$ with optimal spacing computed as $0.2 \mathrm{~m}$. Although above $0.4 \mathrm{~m}$ there is an increase in power generation, the costs of elevating the PV modules may not be compensated and raising too much, the solar panels can lead to a stability of the mounting structure (see Figure 15).

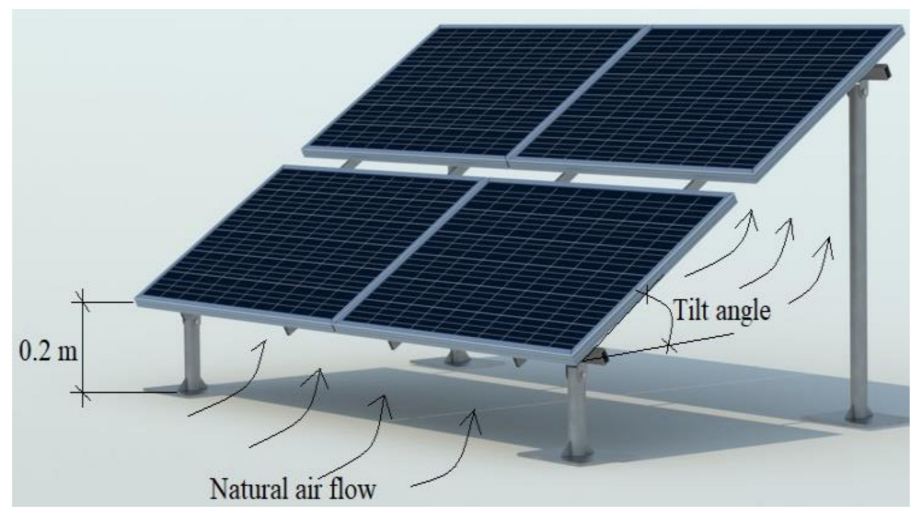

Figure 15. PV module mounting gap representation. Courtesy of https://grabcad.com/library/ solar-panel-mounting-structure-2 (accessed on 12 May 2021) [41].

The cell efficiency plays a key role in the fabrication of PV modules as it directly impacts in the decrease of cell processing costs [42]. Consequently, the decline in efficiency with the heating of the PV module requires the use of high efficiency panels and therefore more expensive, as in the case of monocrystalline PV modules [42,43]. According to [44,45] the cell temperature has a significant effect on the solar PV module operation and it controls the quality and performance of the solar cell. The open circuit voltage, maximum power, and efficiency are found to be decreased with cell temperature. 
As it is observed in Figure 16, the PV module efficiency increased in the morning, from 5:00 a.m. to 7:00 a.m. and remained constant for one hour when the cell temperature was increasing from 20 to $40^{\circ} \mathrm{C}$. After $40^{\circ} \mathrm{C}$, the increase in cell temperature led to a decline of module efficiency. At maximum cell temperature (aproximately $50{ }^{\circ} \mathrm{C}$ when it was 12:00 a.m.), the module efficiency was the lowest (approximately 13\%). When the module began cooling in the afternoon, its efficiency increased again and then fell at sunset.

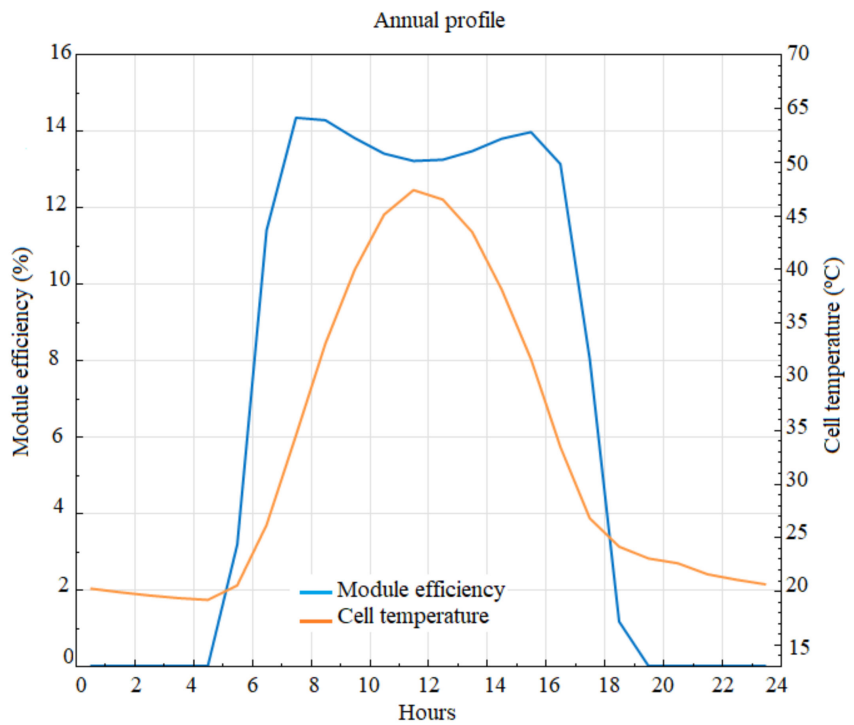

Figure 16. Effect of heating on the module efficiency (tilt angle $=20^{\circ}$ and azimuth angle $=10^{\circ}$ ).

Although the reduction of module efficiency occurred with the rise in cell temperature, energy generation increased with the increase in solar incidence radiation. As it can be seen in Figure 17, at 12:00 o'clock the efficiency of the module decreased but at that time, the power production was higher because the solar incident radiation was also higher as illustrated in Figure 18.

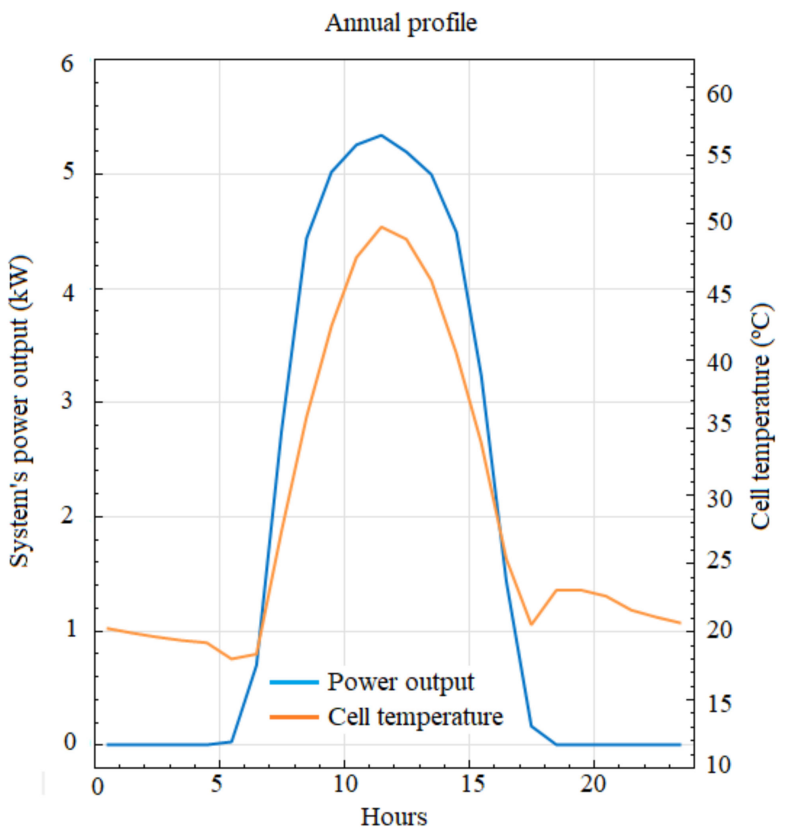

Figure 17. Relation between the cell temperature and power output (tilt angle $=23^{\circ}$ and azimuth angle $=11^{\circ}$ ). 


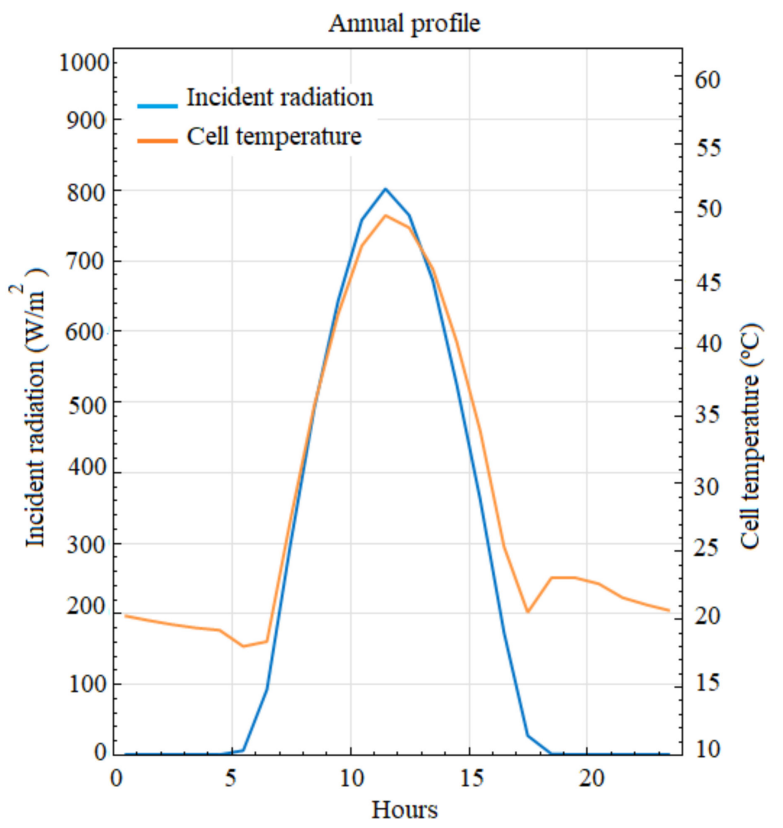

Figure 18. Relation between the cell temperature and incident radiation (tilt angle $=23^{\circ}$ and azimuth angle $=11^{\circ}$ ).

Once the negative effect of overheating the module cells due to excessive incident radiation is proven, many research have revealed technical measures that could minimize the impact of increased cell temperature on the performance of solar modules [43-48]. In this study, in addition to examining the effect of the gap between the PV panel and the wall, the effect of the temperature at the backside of the module was also investigated. The range of temperatures at the backside of the module was considered and the power output system and the cell temperature module were also analyzed. As can be seen in Figure 19, keeping the backside of the panel at temperatures below the standard cell temperature of the module minimized the cell heating and increased energy production.

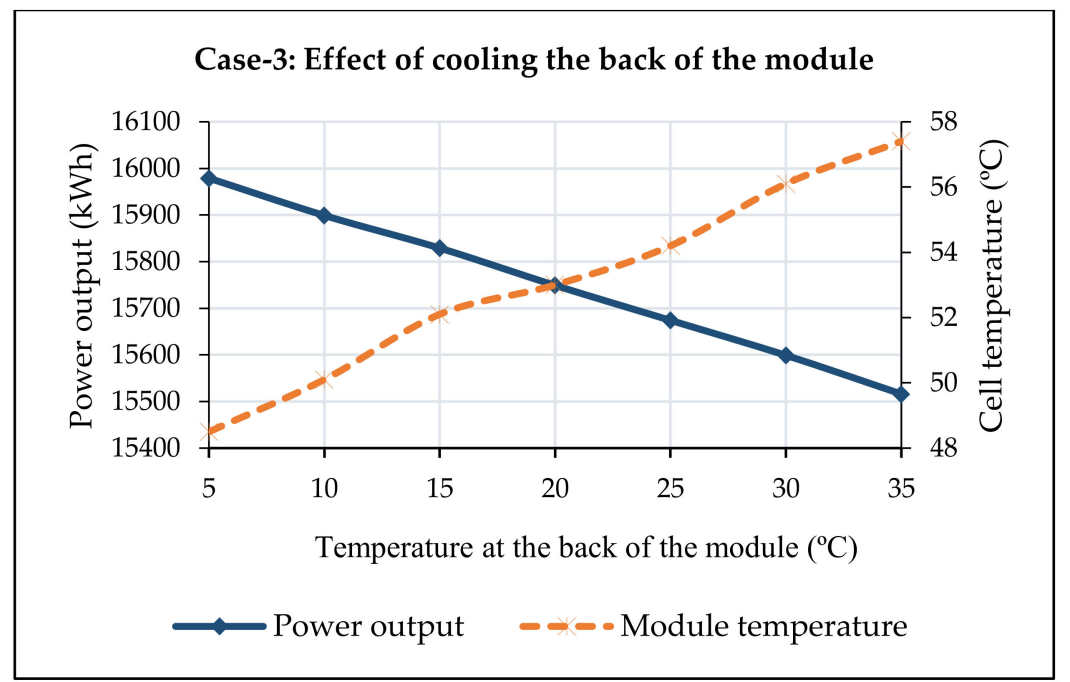

Figure 19. Effect of cooling the back of the module.

It has been previously concluded by some studies that by tracking the sun, solar PV systems can maximize the power generation by setting the module in such a way to get maximum sunlight [1]. Tracking PV panels in the direction of the sun can increase power output between $15 \%$ and $35 \%$, relative to fixed mounted PV installations [40,41]. Figure 20 shows the variation of the azimuth angle and the system's power in September. It can be 
observed that at 6:30 a.m., the azimuth angle was $80^{\circ}$ and gradually varied until reaching $30^{\circ}$ at 11:30 a.m. After this stage the module was moved rapidly to $320^{\circ}$ (or $-40^{\circ}$ ) and gradually varied until reaching $280^{\circ}\left(-80^{\circ}\right)$. By tracking the sun trajectory, the system's annual power generation increased from $15,764 \mathrm{kWh}$ to $17,898 \mathrm{kWh}$, representing a growth of $13.54 \%$.

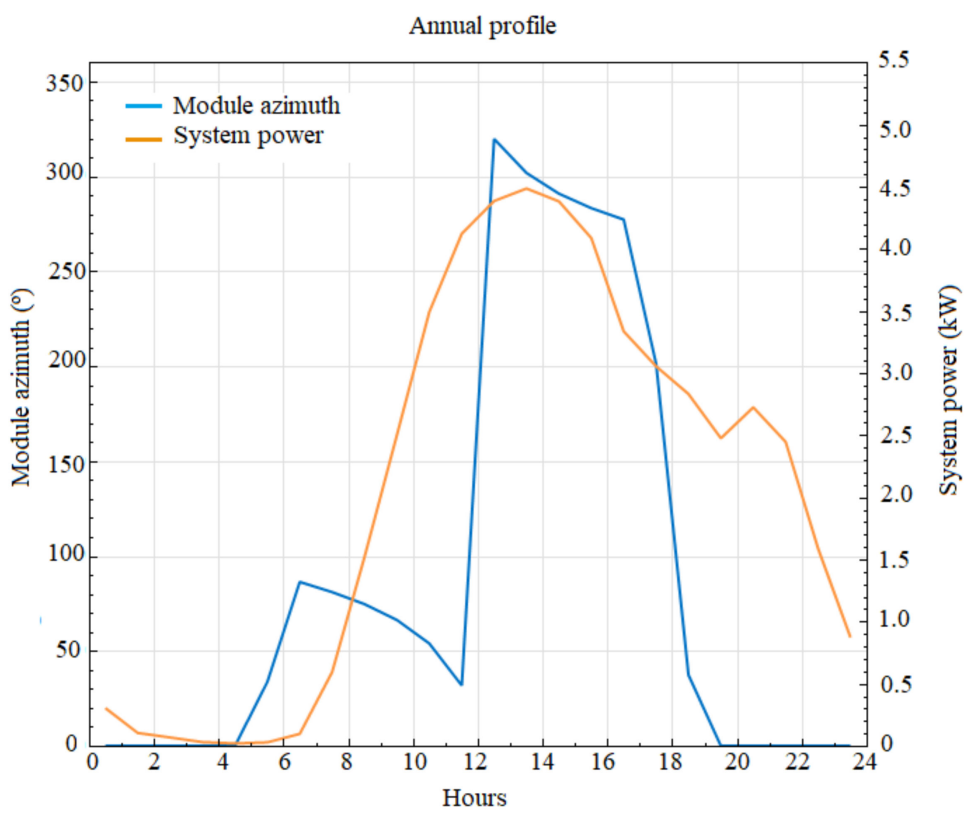

Figure 20. Variation of the module's azimuth angle with the sun trajectory.

\section{Conclusions}

Worldwide, the installation of stand-alone solar PV systems has demonstrated to significantly be contributing to the access of energy in rural areas and to be minimizing the pressure that the national electricity network suffers from the increase in power demand. However, despite this growing contribution, basic challenges still persist with regard to optimal sizing and installation of solar PV modules. In this study, HOMER optimized the size of the solar PV system and SAM tracked the module's best slope and azimuth angles installation and investigated the effect of the gap between the PV module and the mounting wall and the impact of temperature at the back of the solar PV panel. Considering the building's load profile, it was observed from the results that the solar PV system capacity was $12.6 \mathrm{~kW}$. Since the module installation procedure can greatly affect the performance of the PV system it was concluded that for Maputo region, the optimal tilt angle was approximately $23 \pm 2^{\circ}$ while the best azimuth angle was about $11 \pm 1^{\circ}$. In addition, using the recommended angles for the site, it is prudent to keep the backside of the module ventilated, because excessive heating reduces the efficiency of the module cell. In that context, keeping the backside of the panel at temperatures below the standard cell temperature of the module $\left(T_{\text {Back }}<20^{\circ} \mathrm{C}\right)$, minimizes the cell heating and increases energy production. The elevation of the PV module is strongly recommended when installing PV panels in order to guarantee the natural air flow. The optimal distance between the module and the mounting roof was $0.2 \mathrm{~m}$. Although above $0.4 \mathrm{~m}$ there was an increase in power generation, the costs of elevating the PV modules might not be compensated.

Author Contributions: Conceptualisation, P.M.J.R., S.P.D.C., and Z.H.; Methodology, P.M.J.R., and S.P.D.C.; Validation, P.M.J.R., S.P.D.C., and Z.H.; formal analysis, P.M.J.R., S.P.D.C., and Z.H.; investigation, P.M.J.R., S.P.D.C., and Z.H.; resources, P.M.J.R.; data curation, P.M.J.R., S.P.D.C., and Z.H.; writing-original draft preparation, P.M.J.R. and S.P.D.C.; writing-review and editing, P.M.J.R., S.P.D.C., and Z.H.; visualisation, P.M.J.R., S.P.D.C., and Z.H. All authors have read and agreed to the published version of the manuscript. 
Funding: This research received no external funding.

Institutional Review Board Statement: Not applicable.

Informed Consent Statement: The authors hereby agree to publish this paper as Co-Authors in the sequence of Names as above on the basis of our (1) contributions and participations in formulating the research problem, or analysing and interpreting the data or have made other substantial scholarly effort or a combination of these; and/or (2) participations in writing the paper; and (3) approvals of the final version for publication and preparedness to defend the publication against criticisms.

Data Availability Statement: Data collected from FUNAE, Mozambique with permission.

Acknowledgments: The authors would like to acknowledge the Tshwane University of Technology, Departments of Electrical and Mechanical and Mechatronics Engineering, Pretoria, South Africa, for all the conditions provided in order to conduct the research and writing of this paper.

Conflicts of Interest: The authors declare no conflict of interest.

\section{References}

1. Gupta, P.; Kumar, B.; Wankhade, P.; Choudhary, P.; Singh, A.; Tiwari, A.K.; Singh, A.; Soni, A.; Shrivastana, N.; Bisen, N. Azimuth-Altitude Dual Axis Solar Tracker. IOSR J. Electr. Electron. Eng. 2016, 11, 26-30. [CrossRef]

2. Stanislawski, B.; Margairaz, F.; Cal, R.; Calaf, M. Potential of module arrangements to enhance convective cooling in solar photovoltaic arrays. Renew. Energy 2020, 157, 851-858. [CrossRef]

3. Keshavarz, S.A.; Talebizadeh, P.; Adalatia, S.M.; Mehrabian, A.; Abdolzadeh, M. Optimal slope-angles to determine maximum solar energy gain for solar collectors used in Iran. Int. J. Renew. Energy Res. 2012, 2, 665-673.

4. Kumar, N.M.; Gupta, R.P.; Mathew, M.; Jayakumar, A.; Singh, N.K. Performance, energy loss, and degradation prediction of roof-integrated crystalline solar PV system installed in Northern India. Case Stud. Therm. Eng. 2019, 13, 100409. [CrossRef]

5. He, G.; Kammen, D.M. Where, when and how much solar is available? A provincial-scale solar resource assessment for China. Renew. Energy 2016, 85, 74-82. [CrossRef]

6. Darhmaoui, H.; Lahjouji, D. Latitude Based Model for Tilt Angle Optimization for Solar Collectors in the Mediterranean Region. Energy Procedia 2013, 42, 426-435. [CrossRef]

7. Armstrong, S.; Hurley, W. A thermal model for photovoltaic panels under varying atmospheric conditions. Appl. Therm. Eng. 2010, 30, 1488-1495. [CrossRef]

8. Chander, S.; Purohit, A.; Sharma, A.; Nehra, S.; Dhaka, M. Impact of temperature on performance of series and parallel connected mono-crystalline silicon solar cells. Energy Rep. 2015, 1, 175-180. [CrossRef]

9. Gkaidatzis, P.A.; Bouhouras, A.S.; Sgouras, K.I.; Doukas, D.I.; Christoforidis, G.C.; Labridis, D.P. Efficient RES Penetration under Optimal Distributed Generation Placement Approach. Energies 2019, 12, 1250. [CrossRef]

10. Udayakumar, M.; Anushree, G.; Sathyaraj, J.; Manjunathan, A. The impact of advanced technological developments on solar PV value chain. Mater. Today Proc. 2021, 45, 2053-2058. [CrossRef]

11. Shen, L.; Li, Z.; Ma, T. Analysis of the power loss and quantification of the energy distribution in PV module. Appl. Energy 2020, 260, 114333. [CrossRef]

12. Tan, L.; Date, A.; Fernandes, G.; Singh, B.; Ganguly, S. Efficiency Gains of Photovoltaic System Using Latent Heat Thermal Energy Storage. Energy Procedia 2017, 110, 83-88. [CrossRef]

13. Tan, L.; Date, A.; Zhang, B.; Singh, B.; Ganguly, S. A Comparative Case Study of Remote Area Power Supply Systems Using Photovoltaic-battery vs Thermoelectric-battery Configuration. Energy Procedia 2017, 110, 89-94. [CrossRef]

14. Khosravi, A.; Rodriguez, O.R.S.; Talebjedi, B.; Laukkanen, T.; Pabon, J.J.G.; Assad, M.E.H. New Correlations for Determination of Optimum Slope Angle of Solar Collectors. Energy Eng. 2020, 117, 249-265. [CrossRef]

15. Jacobson, M.Z.; Jadhav, V. World estimates of PV optimal tilt angles and ratios of sunlight incident upon tilted and tracked PV panels relative to horizontal panels. Sol. Energy 2018, 169, 55-66. [CrossRef]

16. Kuttybay, N.; Saymbetov, A.; Mekhilef, S.; Nurgaliyev, M.; Tukymbekov, D.; Dosymbetova, G.; Meiirkhanov, A.; Svanbayev, Y. Optimized Single-Axis Schedule Solar Tracker. Energies 2020, 13, 5226. [CrossRef]

17. Jain, D.; Lalwani, M. A review on optimal inclination angles for solar arrays. Int. J. Renew. Energy Res. 2017, 7, $1053-1061$.

18. Goswami, D.Y. Principles of Solar Engineering, 3rd ed.; CRC Press: Boca Raton, FL, USA, 2015.

19. Heide, D.; von Bremen, L.; Greiner, M.; Hoffmann, C.; Speckmann, M.; Bofinger, S. Seasonal optimal mix of wind and solar power in a future, highly renewable Europe. Renew. Energy 2010, 35, 2483-2489. [CrossRef]

20. Muñoz, Y.; Orlando, V.; Gustavo, P.; Jairo, V. Sizing and Study of the Energy Production of a Grid-Tied Photovoltaic System Using PV syst Software. Tecciencia 2016, 12, 27-32. [CrossRef]

21. Zappa, W.; Broek, M.V.D. Analysing the potential of integrating wind and solar power in Europe using spatial optimisation under various scenarios. Renew. Sustain. Energy Rev. 2018, 94, 1192-1216. [CrossRef]

22. Liu, W.H.; Alwi, S.R.W.; Hashim, H.; Muis, Z.A.; Klemeš, J.J.; Rozali, N.E.M.; Lim, J.S.; Ho, W.S. Optimal Design and Sizing of Integrated Centralized and Decentralized Energy Systems. Energy Procedia 2017, 105, 3733-3740. [CrossRef] 
23. Soberanis, M.A.E.; Mithrush, T.; Bassam, A.; Mérida, W. A sensitivity analysis to determine technical and economic feasibility of energy storage systems implementation: A flow battery case study. Renew. Energy 2018, 115, 547-557. [CrossRef]

24. Bhuvanesh, A.; Christa, S.J.; Kannan, S.; Pandiyan, M.K. Aiming towards pollution free future by high penetration of renewable energy sources in electricity generation expansion planning. Future 2018, 104, 25-36. [CrossRef]

25. McLellan, B.; Florin, N.; Giurco, D.; Kishita, Y.; Itaoka, K.; Tezuka, T. Decentralised Energy Futures: The Changing Emissions Reduction Landscape. Procedia CIRP 2015, 29, 138-143. [CrossRef]

26. Costa, T.S.; Villalva, M.G. Technical Evaluation of a PV-Diesel Hybrid System with Energy Storage: Case Study in the TapajósArapiuns Extractive Reserve, Amazon, Brazil. Energies 2020, 13, 2969. [CrossRef]

27. Branker, K.; Pathak, M.; Pearce, J. A review of solar photovoltaic levelized cost of electricity. Renew. Sustain. Energy Rev. 2011, 15, 4470-4482. [CrossRef]

28. Popovici, C.G.; Hudişteanu, S.V.; Mateescu, T.D.; Cherecheş, N.-C. Efficiency Improvement of Photovoltaic Panels by Using Air Cooled Heat Sinks. Energy Procedia 2015, 85, 425-432. [CrossRef]

29. Dubey, S.; Sarvaiya, J.N.; Seshadri, B. Temperature Dependent Photovoltaic (PV) Efficiency and Its Effect on PV Production in the World-A Review. Energy Procedia 2013, 33, 311-321. [CrossRef]

30. Hammami, M.; Torretti, S.; Grimaccia, F.; Grandi, G. Thermal and Performance Analysis of a Photovoltaic Module with an Integrated Energy Storage System. Appl. Sci. 2017, 7, 1107. [CrossRef]

31. Yang, H.; Wang, H.; Cao, D.; Sun, D.; Ju, X. Analysis of Power Loss for Crystalline Silicon Solar Module during the Course of Encapsulation. Int. J. Photoenergy 2015, 2015, 1-5. [CrossRef]

32. Cengel, Y.A. Heat Transfer-A Pratical Approach, 2nd ed.; McGraw-Hill Inc.: New York, NY, USA, 2003.

33. Tonui, J.; Tripanagnostopoulos, Y. Improved PV/T solar collectors with heat extraction by forced or natural air circulation. Renew. Energy 2007, 32, 623-637. [CrossRef]

34. Saidan, M.; Albaali, G.; Alasis, E.; Kaldellis, J.K. Experimental study on the effect of dust deposition on solar photovoltaic panels in desert environment. Renew. Energy 2016, 92, 499-505. [CrossRef]

35. Tao, S.; Li, C.; Zhang, L.; Tang, Y. Operational Risk Assessment of Grid-connected PV System Considering Weather Variability and Component Availability. Energy Procedia 2018, 145, 252-258. [CrossRef]

36. Sharma, M.K.; Kumar, D.; Dhundhara, S.; Gaur, D.; Verma, Y.P. Optimal Tilt Angle Determination for PV Panels Using Real Time Data Acquisition. Glob. Chall. 2020, 4, 1900109. [CrossRef] [PubMed]

37. National Renewable Energy Laboratory. System Advisor Model (SAM); NREL: Golden, CO, USA, 2020.

38. FUNAE. Renewable Energy Atlas of Mozambique; Gesto Energia S.A.: Maputo, Mozambique, 2014.

39. HOMER Energy. HOMER Pro. Available online: https://www.homerenergy.com/products/pro/index.html (accessed on 13 February 2021).

40. EDM. Annual Statistical Report 2016; EDM: Maputo, Mozambique, 2016.

41. Solar-panel-mounting-structure-2. Available online: https://grabcad.com/library/solar-panel-mounting-structure-2 (accessed on 12 May 2021).

42. Benda, V.; Černá, L. PV cells and modules—State of the art, limits and trends. Heliyon 2020, 6, e05666. [CrossRef]

43. Tuncel, B.; Ozden, T.; Balog, R.S.; Akinoglu, B.G. Dynamic thermal modelling of PV performance and effect of heat capacity on the module temperature. Case Stud. Therm. Eng. 2020, 22, 100754. [CrossRef]

44. Hanifi, H.; Pander, M.; Zeller, U.; Ilse, K.; Dassler, D.; Mirza, M.; Bahattab, M.A.; Jaeckel, B.; Hagendorf, C.; Ebert, M.; et al. Loss analysis and optimization of PV module components and design to achieve higher energy yield and longer service life in desert regions. Appl. Energy 2020, 280, 116028. [CrossRef]

45. Ameur, A.; Berrada, A.; Loudiyi, K.; Aggour, M. Forecast modeling and performance assessment of solar PV systems. J. Clean. Prod. 2020, 267, 122167. [CrossRef]

46. Mulcué-Nieto, L.F.; Echeverry-Cardona, L.F.; Restrepo-Franco, A.M.; García-Gutiérrez, G.A.; Jiménez-García, F.N.; Mora-López, L. Energy performance assessment of monocrystalline and polycrystalline photovoltaic modules in the tropical mountain climate: The case for Manizales-Colombia. Energy Rep. 2020, 6, 2828-2835. [CrossRef]

47. Chander, S.; Purohit, A.; Sharma, A.; Nehra, S.; Dhaka, M. A study on photovoltaic parameters of mono-crystalline silicon solar cell with cell temperature. Energy Rep. 2015, 1, 104-109. [CrossRef]

48. Arab, A.H.; Taghezouit, B.; Abdeladim, K.; Semaoui, S.; Razagui, A.; Gherbi, A.; Boulahchiche, S.; Mahammed, I.H. Maximum power output performance modeling of solar photovoltaic modules. Energy Rep. 2020, 6, 680-686. [CrossRef] 